\title{
Application of a Diffusion-denuder Method for the Investigation of the Effects of "Smoke pH" on Vapor-phase Nicotine Yields from Different Types of Cigarettes*
}

\author{
by \\ Emily W. Cochran, Melissa J. Joseph, Stacy L. Stinson, and Stacie S. Summers \\ A.W. Spears Research Center, Lorillard Tobacco Company, Greensboro, NC 27405, USA
}

\section{SUMMARY}

The potential effects of smoke $\mathrm{pH}$ on vapor-phase nicotine, or unprotonated nicotine, were investigated using a diffusion denuder method selected for its ability to quantitatively monitor vapor-phase nicotine in the presence of smoke particulate. For the purpose of this paper, the $\mathrm{pH}$ of the water-soluble fraction of mainstream cigarette smoke will be referred to as "smoke pH". In this study, samples with different construction parameters affecting smoke $\mathrm{pH}$ were analyzed for percent vapor-phase nicotine. The smoke $\mathrm{pH}$ values ranged from 5.87 to 7.79. Percent initial vapor-phase nicotine values ranged from $0.4 \%$ to $1.5 \%$. The range of the vapor-phase nicotine values for this study was (a) independent of smoke $\mathrm{pH}$ and (b) potentially dependent upon cigarette construction. In a second experiment, cigarettes with the same construction were used to repeat the analysis, thus eliminating construction as a variable. The tobacco was treated with varying levels of urea to give a range in smoke $\mathrm{pH}$ from 6.47 to 7.15 . The determined initial vaporphase nicotine values ranged from $0.4 \%$ to $2.1 \%$ of the total mainstream smoke nicotine. This variation was independent of smoke pH. It was determined in this study that (a) the maximum initial vapor-phase nicotine delivered to mainstream smoke was $2.1 \%$ of the total nicotine delivered for our cigarette samples and (b) the delivery of the unprotonated nicotine to mainstream smoke was not meaningfully affected by changes in smoke $\mathrm{pH}$ within the range studied. [Beitr. Tabakforsch. Int. 20 (2003) 365-372]

\section{ZUSAMMENFASSUNG}

Die möglichen Auswirkungen des Rauch pH-Wertes auf Gasphasen-Nikotin oder unprotoniertes Nikotin wurden mithilfe einer Diffusions-Dinuder-Methode untersucht, die es ermöglichte, Gasphasen-Nikotin in Gegenwart von Partikelphasenrauch zu bestimmen. Zum besseren Verständnis wird in dieser Arbeit der pH-Wert des wasserlöslichen Anteils des Hauptstromrauchs von Zigaretten ,Rauch pH“ genannt. In dieser Studie wurden Proben mit unterschiedlichen Konstruktionsparametern, die den Rauch pH-Wert beeinflussen, bezüglich ihres Gasphasen-Nikotins analysiert. Die Rauch $\mathrm{pH}-$ Werte reichten von 5,87 bis 7,79. Der prozentuale Anteil des Gasphasen-Nikotins lag bei $0,4 \%$ bis $1,5 \%$. Die Schwankungsbreite der Gasphasen-Nikotinmengen war in dieser Studie (a) unabhängig vom Rauch pH-Wert und (b) in hohem Maße abhängig von den Konstruktionsmerkmalen der Zigaretten. In einem zweiten Experiment wurde die Untersuchung mit Zigaretten, die dieselben Konstruktionsmerkmale aufwiesen, wiederholt, um den Einfluss der Konstruktionsmerkmale auszuschließen. Der Tabak wurde mit unterschiedlichen Mengen an Harnstoff behandelt, um Rauch pHWerte von 6,47 bis 7,15 zu erhalten. Die ermittelten Gasphasen-Nikotinmengen betrugen zwischen $0,4 \%$ bis $2,1 \%$ des gesamten Hauptstromrauch-Nikotins. Die Variation war vom Rauch $\mathrm{pH}-$ Wert unabhängig. In dieser Studie wurde festgestellt, dass (a) das maximale Gasphasen-Nikotin, das im Hauptstromrauch freigesetzt wurde, bei den in dieser Studie untersuchten Proben 2,1\% des gesamten freigesetzten Nikotins betrug und (b) die Freisetzung des unprotonierten Nikotins in den Hauptstromrauch nicht nachhaltig durch Veränderungen des Rauch $\mathrm{pH}-$ Wertes im hier untersuchten Bereich beeinflusst wurde. [Beitr. Tabakforsch. Int. 20 (2003) 365-372]

\section{RESUME}

Les effets potentiels du $\mathrm{pH}$ de la fumée sur la nicotine en phase vapeur dans la fumée du courant principal, ou nicotine non protonée, ont été étudiés par une méthode de 
diffusion au moyen de tubes dénudeurs, permettant le dosage de la nicotine en phase vapeur en présence de particules. Par rapport à l' objectif de cette étude, le pH de la fraction de la fumée principal de cigarette soluble dans l' eau sera dénommée «pH de la fumée». Dans cette étude, des échantillons avec des paramètres de construction variables affectant le $\mathrm{pH}$ de la fumée ont été analysés pour déterminer le pourcentage de nicotine en phase vapeur. Les valeurs du $\mathrm{pH}$ de la fumée vont de 5,87 à 7,79. Le pourcentage initial de nicotine en phase vapeur va de $0,4 \%$ à $1,5 \%$. La gamme de valeurs pour la nicotine en phase vapeur mesurées dans cette étude est (a) indépendante du pH de la fumée et (b) fortement dépendante de la construction de la cigarette. Dans une deuxième étude, l'analyse a été répétée avec des cigarettes de la même construction pour ainsi éliminer la construction comme variable. Le tabac a été traité avec divers niveaux d' urée pour obtenir une gamme de $\mathrm{pH}$ de la fumée allant de 6.47 à 7.15. Les valeurs initiales déterminées pour la nicotine en phase vapeur vont de $0.4 \%$ à $2.1 \%$ de la nicotine totale du courant principal. La variation est indépendante du $\mathrm{pH}$ de la fumée. Il a été déterminé dans cette étude que (a) la nicotine en phase vapeur initiale maximale délivrée au courant principal est de $2,1 \%$ de la nicotine totale délivrée des échantillons utilisés dans cette étude et que (b) le rendement en nicotine non protonée dans la fumée du courant principal n' est pas influencé de façon significative par des variations de $\mathrm{pH}$ de la fumée telles qu' elles sont étudiées dans cette étude. [Beitr. Tabakforsch. Int. 20 (2003) 365-372]

\section{INTRODUCTION}

Mainstream tobacco smoke is a complex mixture consisting of both a particulate phase and a vapor phase. Within these two phases there are a large number of organic compounds, including nicotine $(1,24)$. Nicotine is present in cigarette smoke as a protonated salt and as an unprotonated freebase. Both forms are present in the particulate phase, but only the unprotonated form has been found in the vapor phase (2-4). Quantitating nicotine in the vapor phase is dependent upon many factors (5-9). Sampling technique is one of the factors that will affect the detection of vaporphase nicotine in mainstream smoke.

Several sampling techniques described in the literature that collect the vapor phase of mainstream smoke after trapping the particulate phase on a filter were investigated (4,9-12). One such method, described by PANKOw et al. (13), was reviewed but was excluded from consideration due to the fact that the method exposed a filter containing previously collected cigarette smoke particulate to a flow of gaseous ammonia and then the amount of unprotonated nicotine released from the particulate was determined. This technique did not attempt to model realistic smoking conditions. Our interest was to directly monitor the nicotine present in the dynamic vapor phase of mainstream cigarette smoke while approximating actual smoking conditions.

Other methods found in the literature were used to evaluate nicotine in environmental tobacco smoke (ETS). In these methods, the ETS was passed through a filtering device to collect the particulate, and then the remaining vapor-phase nicotine was collected downstream on a resin trap $(5,7,9$,
14). The filtering device was either a glass fiber filter pad, a Teflon pad, or an electrostatic precipitator. When these methods were applied to monitor the vapor-phase nicotine in mainstream smoke, the filtering devices interfered with the collection of the vapor-phase nicotine. These interferences varied based on the filtering device and included the release of nicotine from particulate on the filter, as well as retention of the vapor-phase nicotine by the filter (7). These interferences produced inconsistent and inaccurate results when attempting to quantitate the vapor-phase nicotine collected by the resin.

Through further investigation of the literature, a method that would collect the vapor-phase nicotine through diffusion sampling prior to collecting the particulate was found, and this method was viewed as a more appropriate sampling technique than the techniques described in the previous paragraphs. This technique selectively collects nicotine from the vapor phase onto the walls of an acid coated glass tube, or denuder, while allowing the particulate phase to pass through and be collected on a filter located at the end. The use of this technique prevents any interference from the collected particulate and provides a more realistic representation of the nicotine distribution experienced during a smoker's puff. Detailed descriptions of the diffusion sampling technique are reported in the literature $(5,6,9$, 14-18). Because the gas-liquid phases of the smoke sample are in a dynamic equilibrium, some of the nicotine collected onto the walls of the denuder will be due to vapor-phase nicotine that has evaporated from the particulate phase as the mainstream smoke traveled through the tube. LEWIS et al. have described a series of equations which may be employed to quantitate the amount of nicotine evaporating from the particulate phase into the vapor phase and collecting onto the walls of the denuder (6). The application of these equations allows for the determination of the initial percentage of nicotine in the vapor phase, as well as the total amount of nicotine that could be released into the vapor phase from the particulate.

There have been investigations into potential factors that may affect the percentage of nicotine found in the vapor phase of the mainstream smoke $(13,19,23)$. For example, it has been speculated that an increase in the $\mathrm{pH}$ of the watersoluble fraction of cigarette smoke might cause a significant increase in the percentage of nicotine present in the vapor phase of mainstream smoke (13). For the purpose of this paper, the $\mathrm{pH}$ of the water-soluble fraction of cigarette smoke will be referred to as "smoke $\mathrm{pH}$ ". Our study has applied a modification of the denuder method described by LEWIS et al. to determine if quantifiable changes occurred in the vapor-phase nicotine of mainstream smoke as a result of changes in smoke $\mathrm{pH}$.

\section{EXPERIMENTAL}

\section{Denuder configuration}

The denuder tube was constructed from a $60 \mathrm{~cm}^{\text {Pyrex }}{ }^{\mathrm{TM}}$ glass tube (Corning 7740) with an inner diameter of 0.78 $\mathrm{cm}$ and $18 / 9$ ball joints at each end. The inner walls of the tube were coated with oxalic acid by "wetting" the surface with a solution composed of $10 \%$ (w/v) oxalic acid in 


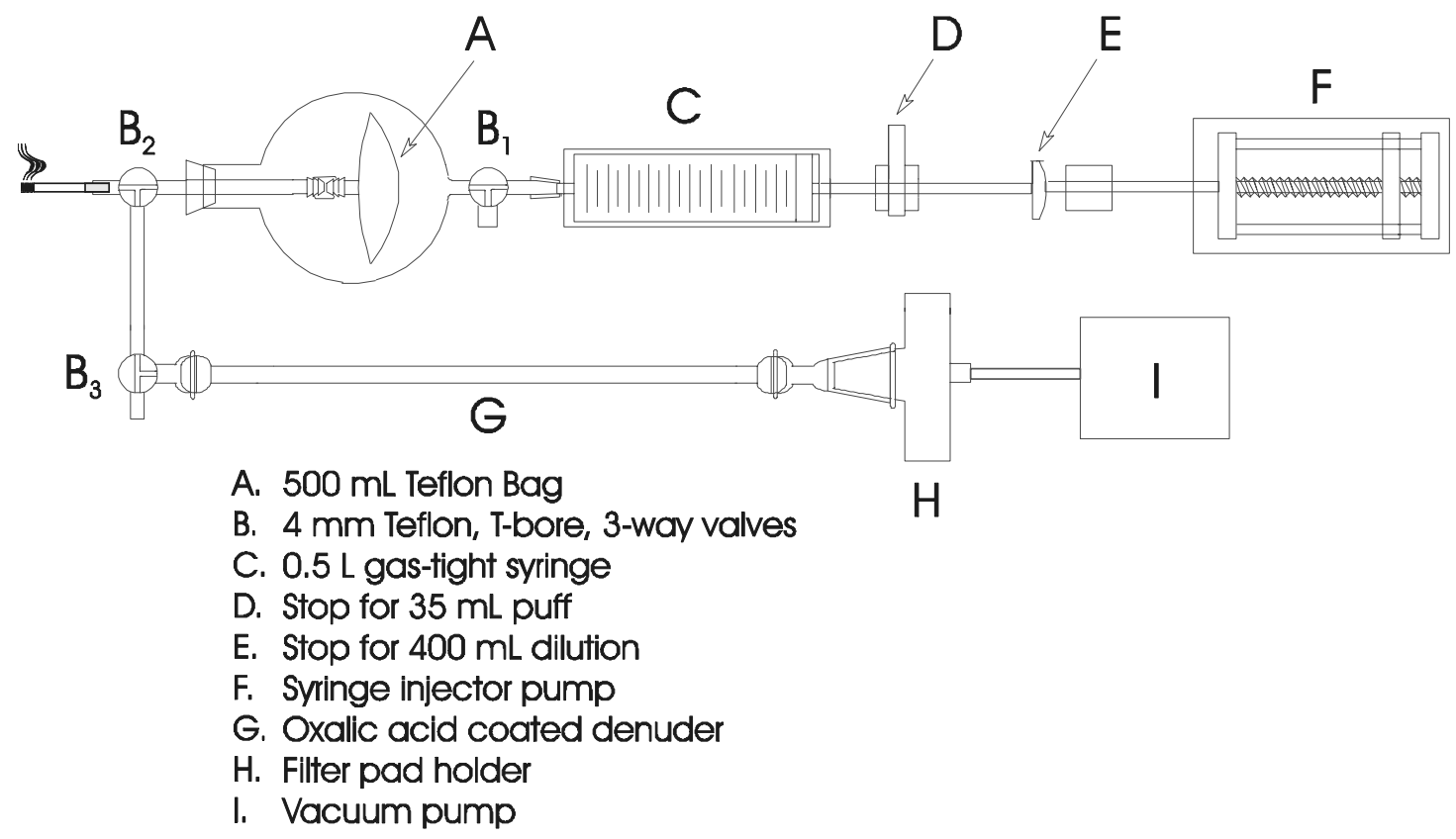

Figure 1. Schematic diagram of experimental configuration

HPLC grade methanol (Fisher Scientific, Pittsburgh, PA) and then evaporating the methanol by forcing filtered air through the tube. The ball joints, which are approximately $2 \mathrm{~cm}$ in length, were uncoated. In order to preserve the integrity of the coating, the denuder tubes were stored under helium until used.

The sampling apparatus is shown in Figure 1. A cigarette was placed in the apparatus and a puff was taken by pulling back on the plunger of the gas tight syringe to the determined puff volume. The Teflon ${ }^{\mathrm{TM}}$ bag inflated (Fisher Scientific), thus drawing in smoke as the plunger was pulled back. The valving system was then adjusted to allow ambient air to enter the system at site $\mathrm{B}_{3}$, and the syringe's plunger was pulled back further to a set dilution volume. In this study, each puff was diluted to a total volume of 400 $\mathrm{mL}$, which was an approximation of the dilution that would occur during the smoking process. The valving system was then aligned to direct the diluted smoke through the denuder tube, which was horizontally oriented. The bag was evacuated by using the syringe injector pump set to automatically depress the syringe's plunger at a rate of 2.00 $\mathrm{mL} / \mathrm{sec}$. The flow rate chosen established a laminar flow rate through the denuder as described by LEWIS et. al. (6). The distance between valve $B_{3}$ and the entrance to the denuder was designed to allow laminar flow to be established prior to the smoke coming into contact with the denuder's coating (6). After passing through the denuder tube, the diluted smoke was filtered at the exit of the tube using a $92 \mathrm{~mm}$ Cambridge filter pad (K.C. Automation, Richmond, VA). Once the Teflon ${ }^{\mathrm{TM}}$ bag was completely evacuated, the system was adjusted to allow ambient air to enter the system at $\mathrm{B}_{3}$. Using a vacuum pump connected behind the Cambridge filter, a continuous flow of ambient air was maintained through the system, which prevented the gravitational "settling out" of any smoke constituents that remained in the apparatus.

\section{Sample collection and preparation}

Standard puff conditions of a $35-\mathrm{mL}$ puff volume, a 2second puff duration, and a 1-minute interim were used to smoke the cigarettes. Cigarettes were not smoked beyond the standard butt length of $3 \mathrm{~mm}$ from the tipping paper. Because it took longer than the 1-minute interim to evacuate the Teflon ${ }^{\mathrm{TM}}$ bag of the $400 \mathrm{~mL}$ of diluted smoke, the cigarettes were initially lit on a Borgwaldt RM 20/CS multi-port smoking machine (Borgwaldt Technik GmbH) and smoked to the desired puff. The cigarettes were then transferred to the denuder apparatus for the desired puff to be collected. The lighting puff and any partial puffs were not collected. Cigarettes having a puff count of eight including the lighting puff required seven cigarettes in order to collect each representative puff on the denuder apparatus. The equivalent of two cigarettes was collected per denuder, with at least three denuders being collected for each sample type.

Extraction of the nicotine from the walls of the denuder was performed by first breaking the denuder into $5-\mathrm{cm}$ segments. Each segment was then placed in a vial containing $5 \mathrm{~mL}$ of $5 \mathrm{M}$ sodium hydroxide (Mallinckrodt, Phillipsburg, $\mathrm{NJ})$ and $1 \mathrm{~mL}$ of a solution composed of Optima grade dichloromethane (Fisher Scientific) and an internal standard (Quinoline, 99+\%ACS grade, Aldrich Chemical Co., Milwaukee, WI). The vials were shaken manually to remove the coating from the denuder walls, then shaken mechanically for $5 \mathrm{~min}$ to ensure complete extraction. The organic phase was then removed with a micropipet and placed into an autosampler vial.

\section{Instrumental analysis of denuder extracts}

The denuder extracts were analyzed using a Hewlett Packard 6890 gas chromatograph equipped with a 5973 
Table 1. Results from a leaf analysis of the urea treated tobacco

\begin{tabular}{l|c|c}
\hline \% Urea & \% Nitrogen & \% Total volatile bases \\
\hline 0.0 & 3.17 & 0.71 \\
0.5 & 3.36 & 0.72 \\
1.0 & 3.55 & 0.77 \\
1.5 & 3.79 & 0.81 \\
2.5 & 4.17 & 0.83 \\
\hline
\end{tabular}

mass selective detector. One-microliter injections were made in triplicate onto a crossbonded 5\% diphenyl capillary column, RTX-5MS $30 \mathrm{~m} \times 0.25 \mathrm{~mm} \times 0.25 \mu \mathrm{m}$ from Restek Corp. (Bellefonte, PA). The injector was set for splitless injection, with the split being enabled after $1 \mathrm{~min}$. The oven profile was set to ramp the oven temperature from $80{ }^{\circ} \mathrm{C}$ to $200{ }^{\circ} \mathrm{C}$ at $40{ }^{\circ} \mathrm{C}$ per minute, and then held at $200{ }^{\circ} \mathrm{C}$ for $7 \mathrm{~min}$. The injection port temperature was set at $240{ }^{\circ} \mathrm{C}$ and the mass spectrometer transfer line was maintained at $290{ }^{\circ} \mathrm{C}$. The detector was set to scan a mass-tocharge ratio of 33 to 200 . The detection limit of nicotine for this method was determined to be $0.01 \mu \mathrm{g} / \mathrm{mL}$.

The denuder extracts were monitored for the presence of particulate by analyzing for solanesol, a smoke particulate marker $(6,26)$. Aliquots of 20 to $200 \mu \mathrm{L}$ of the denuder extracts were injected into a Waters 600S HPLC system equipped with a Perkin Elmer 235 photo-diode array detector. The wavelength of interest was $205 \mathrm{~nm}$. The detector bandwidth, peakwidth, and sensitivity were set to 45,16 , and 0.02 respectively. Separation was achieved by using a Symmetry $C_{8}(4.6 \times 250 \mathrm{~mm}, 5 \mu)$ analytical column, a 95:5 acetonitrile:methanol mobile phase, and a flow rate of $1.2 \mathrm{~mL} / \mathrm{min}$. No solanesol was detected above the detection limit of $0.1 \mu \mathrm{g} / \mathrm{mL}$. Therefore, any particulate adhering to the denuder walls would contribute less than $0.1 \mu \mathrm{g}$ of solanesol per segment.

\section{Determination of total nicotine delivery per cigarette}

The yield of total nicotine per cigarette was determined by smoking cigarettes on a Borgwaldt RM 20/CS multi-port smoking machine and collecting the particulate onto a Cambridge filter pad. Puffing conditions of the Federal Trade Commission (FTC) were used as previously defined, and five cigarettes were smoked per pad. The Cambridge filters were weighed in their holders before and after smoking to determine the total particulate matter (TPM). After smoking, the filters were extracted using $20 \mathrm{~mL}$ of an isopropanol solution containing an internal standard of anethole. The extracts were then analyzed to determine nicotine content using a Perkin Elmer gas chromatograph equipped with a flame ionization detector. Separation was achieved using a Carbowax $15 \mathrm{~m} \times 0.54 \mathrm{~mm} \times 1.2 \mu \mathrm{m}$ column. Nicotine concentrations were determined in milligrams per cigarette. Total nicotine values for the 1R4F reference cigarette sample were taken from the literature (20).

\section{Sample types}

For the first study, variation in smoke $\mathrm{pH}$ was obtained by differences in cigarette construction. Six different samples were analyzed using the denuder method. Five of the samples were cigarette types and the sixth sample was a commercially available, filtered, little cigar. The cigarette types were a $100 \%$ flue-cured cigarette, a $100 \%$ burley cigarette, a commercial non air-diluted cigarette, the same non air-diluted cigarette treated with ammonium carbonate for the purposes of this experiment, and a 1R4F Kentucky reference cigarette (20). The ammonium carbonate treated cigarette was prepared by spraying a commercial tobacco blend with a solution of ammonium carbonate at a level of $2.5 \%(\mathrm{w} / \mathrm{w})$ in order to increase its smoke $\mathrm{pH}$. The cigarette was assembled using a standard, manually operated making machine.

In the second study, cigarette construction was maintained and smoke $\mathrm{pH}$ was varied by treating the tobacco with varying levels of urea. On a pilot plant scale, a tobacco blend was sprayed with urea to give approximately the following concentrations $0.0 \%, 0.5 \%, 1.0 \%, 1.5 \%$, and $2.5 \%(\mathrm{w} / \mathrm{w})$. Cigarettes were then made using a pilot plant cigarette maker. The results from a percent nitrogen and percent total volatile base analysis for each tobacco sample indicated that the urea was applied at incremental amounts (Table 1).

\section{pH Determination}

The $\mathrm{pH}$ for each sample type was determined by smoking cigarettes on the Borgwaldt RM 20/CS multi-port smoking machine and collecting the particulate on a Cambridge filter. A blank filter pad with $50 \mathrm{~mL}$ of deionized, filtered water (Milli-Q Gradient A10, Millipore Corp., Bedford, MA) should have a $\mathrm{pH}$ of $7 \pm 0.5$. Standard puff conditions were used as previously defined and five cigarettes were smoked per filter. The filters were then placed in a beaker and covered with $50 \mathrm{~mL}$ of the deionized, filtered water. A stir bar was placed on top of the pad and the solution was stirred for 2 min. Stirring was stopped and the $\mathrm{pH}$ was taken using a gel/epoxy combination $\mathrm{pH}$ probe attached to a VWR $2000 \mathrm{pH}$ meter. Triplicate analyses were performed for each sample type $(21,22)$.

\section{RESULTS AND DISCUSSION}

For each $5 \mathrm{~cm}$ denuder segment, nicotine was determined and plotted against denuder length. An example is shown in Figure 2. A larger amount of nicotine was detected in the first few denuder segments, with the concentration decreasing exponentially as distance increased from the entrance of the denuder. This behavior was consistent with the literature and can be attributed to the fact that the nicotine initially in the vapor phase readily partitions to the walls of the denuder within the first few segments $(6,15)$. Therefore, the nicotine detected in the latter segments is predominately due to nicotine released from the particulate into the vapor phase and then partitioning to the denuder walls. For the purpose of this discussion, the nicotine originally entering the denuder as vapor phase will be termed "initial vapor- 


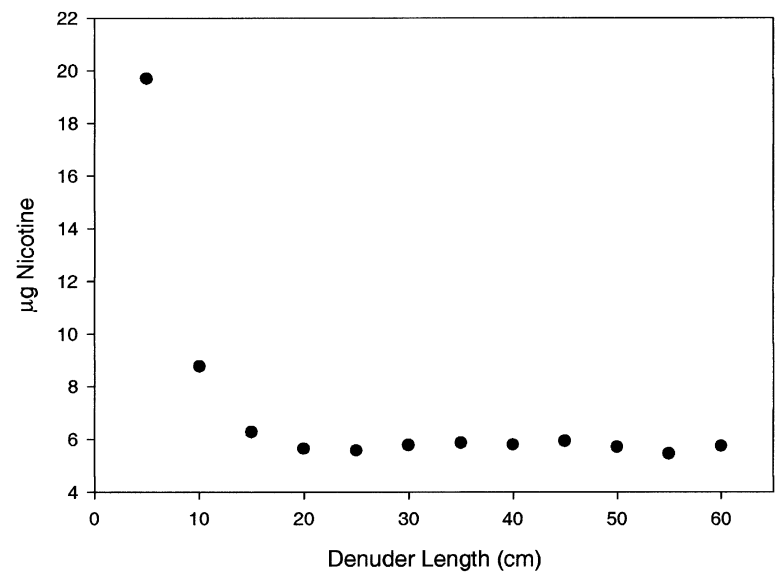

Figure 2. Nicotine $(\mu \mathrm{g})$ per denuder segment for a urea treated sample with a smoke $\mathrm{pH}$ of 6.59

phase nicotine", and nicotine being released from the particulate into the vapor phase will be referred to as "evaporated particulate nicotine".

LEWIS et al. have determined that one can mathematically identify the first denuder segment where there is virtually no initial vapor-phase nicotine remaining in the mainstream smoke $(<0.2 \%)$ and any nicotine contribution is due to evaporated particulate nicotine. To determine this denuder segment mentioned, the following condition must be met: $x / Q>8$, where $x$ is the axial distance in $\mathrm{cm}$ from the entrance of the denuder and $Q$ represents the volumetric flow rate used during the experiment (6). Since $Q$ was equal to $2.00 \mathrm{~mL} / \mathrm{s}$ for our experiments, the nicotine extracted from all denuder segments with an axial distance $\geq 20 \mathrm{~cm}$, the last nine $5 \mathrm{~cm}$ segments, was recognized to come solely from evaporated particulate nicotine.

By applying an exponential regression to the nicotine data obtained for segments with an axial distance $\geq 20 \mathrm{~cm}$, the contribution of evaporated particulate nicotine can be determined for any segment, including those segments where $x / Q<8$ (6). This determination of the mass of evaporated particulate nicotine $\left(m_{j}\right)$ in any given segment $x$ was calculated from the following equation:

$$
m_{j}=k_{A} \exp \left(\frac{-11.49 D_{A} x}{Q}\right)
$$

where $k_{A}$ is a factor related to the rate of nicotine evaporation from the surface of the particulate, $D_{A}$ is the apparent diffusion coefficient for the diffusion of nicotine from the particulate to the walls of the denuder, and $Q$ is the volumetric flow rate $(2.00 \mathrm{~mL} / \mathrm{s})$. The factors $k_{A}$ and $D_{A}$ can be determined from the results of the exponential regression previously determined for segments $\geq 20 \mathrm{~cm}$.

Because the initial vapor-phase nicotine is collected in segments where $x / Q<8$, the majority $(>99.8 \%)$ of the initial vapor phase in our experiments was collected in the first three $5 \mathrm{~cm}$ denuder segments where the axial distance was $\leq 15 \mathrm{~cm}$. However, these segments could also contain evaporated particulate nicotine, which can be determined using Equation [1]. The contribution from the evaporated particulate nicotine was subtracted from the total nicotine measured in the first three segments. The remainder was the nicotine contribution resulting solely from nicotine originally in the vapor phase. An exponential regression applied to these subtracted results allowed for the determination of the factor $k$ which is used to determine the amount of initial vapor-phase nicotine $\left(m_{j}\right)$ present in any segment of the denuder using the following Equation [2]:

$$
m_{j}=k \exp \left(\frac{-11.49 D x}{Q}\right)
$$

This equation is similar to Equation [1] with the exception that $D$ equals the literature value for the diffusion coefficient of the nicotine $(0.065 \mathrm{~mL} / \mathrm{s})$.

Equation [2] was applied to each denuder segment and the results were summed to produce the total amount of initial vapor-phase nicotine $(\mu \mathrm{g})$ collected for each sample type. These values were divided by the amount of total nicotine (mg) determined for each sample, giving a percentage of initial vapor-phase nicotine present in the mainstream smoke. The nicotine and smoke $\mathrm{pH}$ values for samples with different constructions are listed in Table 2 and plotted in Figure 3 . The sample type with the lowest $\mathrm{pH}$, the $100 \%$ flue-cured cigarette $\mathrm{pH} 5.87$, had the lowest percentage of vapor-phase nicotine at $0.4 \%$. The little cigar exhibited the highest $\mathrm{pH}$ of 7.80 , along with the highest percentage of initial vapor-phase nicotine, $1.5 \%$. When only these two individual data points were considered, it initially appeared as if a relationship may exist between smoke $\mathrm{pH}$ and yield of initial vapor-phase nicotine. However, the little cigar possessed a vastly different construction than the rest of the cigarettes evaluated (25). The data was re-evaluated excluding the cigar and there was a poor correlation observed between $\mathrm{pH}$ and percent initial vapor-phase

Table 2. Comparison of \% initial vapor-phase nicotine to $\mathrm{pH}$ and total smoke nicotine for samples with varied constructions

\begin{tabular}{lcccc}
\hline Sample & Smoke $\mathrm{pH}^{\mathrm{a}}$ & $\begin{array}{c}\text { Total smoke nicotine } \\
(\mathrm{mg} / \mathrm{cig})^{\mathrm{a}}\end{array}$ & $\begin{array}{c}\text { Initial vapor-phase } \\
\text { nicotine }(\mu \mathrm{g} / \mathrm{cig})^{\mathrm{a}}\end{array}$ & $\begin{array}{c}\text { \% Initial vapor-phase } \\
\text { nicotine }\end{array}$ \\
\hline $100 \%$ flue-cured & $5.87 \pm 0.04$ & $3.21 \pm 0.04$ & $11.4 \pm 1.7$ & 0.4 \\
Commercial non air-diluted & $6.14 \pm 0.24$ & $1.27 \pm 0.10$ & $10.2 \pm 2.8$ & 0.8 \\
$1 \mathrm{R} 4 \mathrm{~F}^{\mathrm{b}}$ & $6.16 \pm 0.19$ & 0.8 & $6.69 \pm 2.26$ & 0.8 \\
$100 \%$ burley & $6.76 \pm 0.03$ & $2.04 \pm 0.06$ & $27.8 \pm 19.5$ & 1.4 \\
Treated non air-diluted & $7.09 \pm 0.08$ & $1.27 \pm 0.07$ & $11.7 \pm 1.4$ & 0.9 \\
Little cigar $^{\mathrm{c}}$ & $7.80 \pm 0.05$ & $1.85 \pm 0.08$ & $27.7 \pm 0.5$ & 1.5 \\
\hline
\end{tabular}

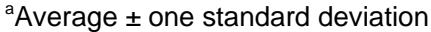

${ }^{\mathrm{b}}$ The total nicotine value for the $1 \mathrm{R} 4 \mathrm{~F}$ cigarette was taken from reference 12.

${ }^{\mathrm{c}}$ The treated non air-diluted cigarettes were treated for experimental purposes with ammonium carbonate to raise the $\mathrm{pH}$ as described in the Experimental section. 


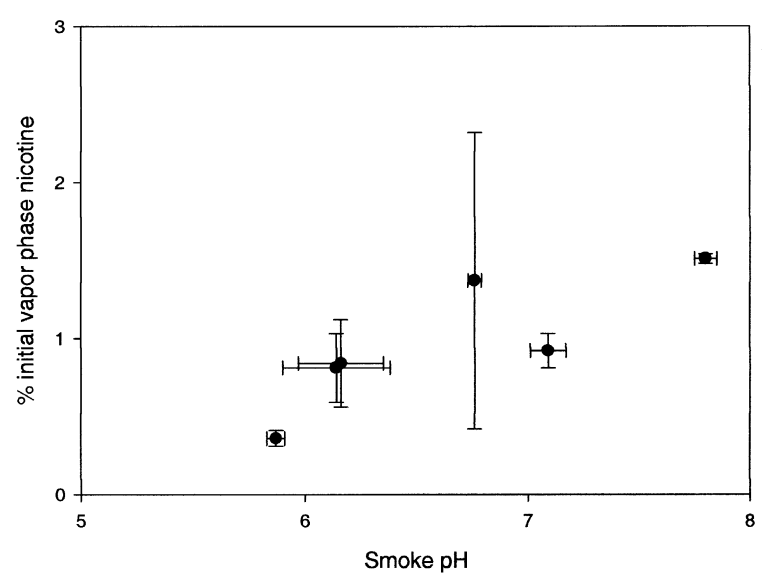

Figure 3. Average percent initial vapor-phase nicotine vs. smoke $\mathrm{pH} \pm$ one standard deviation for all six construction types

Table 3. Comparison of \% initial vapor-phase nicotine to $\mathrm{pH}$ and total smoke nicotine for urea treated cigarettes ${ }^{\mathrm{a}}$

\begin{tabular}{c|c|c|c}
\hline Smoke $\mathrm{pH}^{\mathrm{b}}$ & $\begin{array}{c}\text { Total smoke } \\
\text { nicotine } \\
(\mathrm{mg} / \mathrm{cig})^{\mathrm{b}}\end{array}$ & $\begin{array}{c}\text { Initial vapor- } \\
\text { phase nicotine }^{(\mu \mathrm{g} / \mathrm{cig})^{\mathrm{b}}}\end{array}$ & $\begin{array}{c}\text { \% Initial } \\
\text { vapor-phase } \\
\text { nicotine }\end{array}$ \\
\hline $6.47 \pm 0.15$ & $1.41 \pm 0.02$ & $19.7 \pm 4.9$ & 1.4 \\
$6.59 \pm 0.05$ & $1.37 \pm 0.05$ & $24.2 \pm 2.0$ & 1.8 \\
$6.59 \pm 0.07$ & $1.44 \pm 0.01$ & $5.92 \pm 0.31$ & 0.4 \\
$6.74 \pm 0.03$ & $1.35 \pm 0.07$ & $8.67 \pm 2.20$ & 0.6 \\
$7.15 \pm 0.19$ & $1.55 \pm 0.03$ & $33.1 \pm 7.0$ & 2.1 \\
\hline
\end{tabular}

${ }^{a}$ The urea treated cigarettes were treated for experimental purposes.

${ }^{\mathrm{b} A v e r a g e} \pm$ one standard deviation.

nicotine for any of the other cigarette samples. This was especially evident when comparing the data for the commercial, non air-diluted cigarette and the treated, non airdiluted cigarette. As described in the Experimental section, these two cigarette types possessed the same construction with the exception of the ammonium carbonate which was applied for the purposes of this experiment. The presence of the ammonium carbonate caused the $\mathrm{pH}$ to shift from 6.14 to 7.09 , and yet the percent initial vapor-phase nicotine remained statistically similar when evaluated by the student $t$-test. This suggested that there was some factor other than $\mathrm{pH}$ influencing the percentage of nicotine initially present in the vapor phase.

To make certain that smoke $\mathrm{pH}$ was not influencing the initial vapor-phase nicotine in mainstream smoke, cigarettes with the same construction were used to repeat the analysis, thus eliminating construction as a variable. The tobacco was treated with varying levels of urea to give a range in smoke $\mathrm{pH}$ from 6.47 to 7.15 . The initial vaporphase nicotine and smoke $\mathrm{pH}$ values for these samples are shown in Table 3. The sample with the lowest smoke $\mathrm{pH}$ (6.47) did not have the lowest percentage of vapor-phase nicotine, nor were the vapor-phase nicotine values statistically different from the values of the highest $\mathrm{pH}$ sample. Within this study, no meaningful correlation was observed between initial vapor-phase nicotine and a smoke $\mathrm{pH}$ range

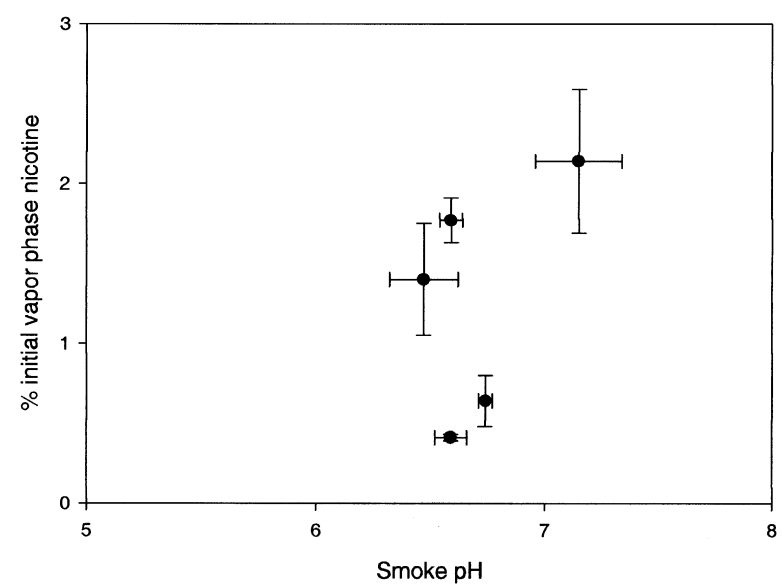

Figure 4. Average percent initial vapor-phase nicotine vs. smoke $\mathrm{pH} \pm$ one standard deviation for urea treated cigarettes

of 6.47 to $7.15\left(r^{2}=0.233\right.$; Figure 4$)$. Based on a statistical evaluation of the regression, the slope was determined not to be different from zero. Similar results were observed in the evaluation of the regression using the corresponding $\left[\mathrm{H}^{+}\right]$concentrations. The correlation between the total amount of nicotine present in the smoke (the total smoke nicotine) per cigarette and the percentage of initial vaporphase nicotine was also poor $\left(r^{2}=0.242\right)$. Statistically the slope was determined not to be different from zero.

In addition to evaluating initial vapor-phase nicotine, the total amount of nicotine that could possibly be present in the vapor phase, either initially or from the particulate was investigated. For the purpose of discussion, this will be referred to as "total vapor-phase nicotine." In order to make this determination, the denuder's length was theoretically extrapolated to $1120 \mathrm{~cm}$ and Equations [1] and [2] were applied over the entire region. This length was chosen since it was the length at which any nicotine adhering to the sides of the denuder segment would have been below the detection limit $(0.01 \mu \mathrm{g} / \mathrm{mL})$ by at least a factor of 10 . The results of these calculations can be seen in Tables 4 and 5 . As with initial vapor-phase nicotine, the $\mu \mathrm{g}$ amount of total vapor-phase nicotine varied with sample type. There was no significant correlation between the yield of total vaporphase nicotine and smoke $\mathrm{pH}$, nor was there a significant correlation between total vapor-phase nicotine and total smoke nicotine $\left(r^{2}=0.614, r^{2}=0.296\right.$, respectively for urea treated cigarettes). Based on a statistical evaluation of the regressions, the slopes were determined not to be different from zero.

\section{CONCLUSION}

This diffusion denuder method allowed for the monitoring of vapor-phase nicotine in the presence of the particulate phase. By using this technique a more realistic smoking model was created compared to prefiltering techniques. Applying the equations developed by LEWIS et al. allowed the initial vapor-phase nicotine and the evaporated particulate nicotine to be quantitatively distinguished.

The lack of a correlation between the percent of initial vapor-phase nicotine and smoke $\mathrm{pH}$ indicated that smoke $\mathrm{pH}$ had little effect on the release of nicotine into the vapor 
Table 4. Comparison of total \% vapor phase nicotine to $\mathrm{pH}$ and total smoke nicotine for samples with varied constructions

\begin{tabular}{lcc|c|c}
\hline Sample & Smoke $\mathrm{pH}^{\mathrm{a}}$ & $\begin{array}{c}\text { Total smoke nicotine } \\
(\mathrm{mg} / \mathrm{cig})^{\mathrm{a}}\end{array}$ & $\begin{array}{c}\text { Total vapor-phase } \\
\text { nicotine }(\mu \mathrm{g} / \mathrm{cig})^{\mathrm{a}}\end{array}$ & $\begin{array}{c}\text { \% Total vapor-phase } \\
\text { nicotine }\end{array}$ \\
\hline $100 \%$ flue-cured & $5.87 \pm 0.04$ & $3.21 \pm 0.04$ & $305 \pm 182$ & 9.5 \\
Commercial non air-diluted & $6.14 \pm 0.24$ & $1.27 \pm 0.10$ & $141 \pm 71$ & 11.1 \\
$1 \mathrm{R}^{\mathrm{b}}$ & $6.16 \pm 0.19$ & 0.8 & $95.9 \pm 9.1$ & 12.0 \\
$100 \%$ burley & $6.76 \pm 0.03$ & $2.04 \pm 0.06$ & $276 \pm 80$ & 13.6 \\
Treated non air-diluted ${ }^{\mathrm{c}}$ & $7.09 \pm 0.08$ & $1.27 \pm 0.07$ & $91.7 \pm 8.5$ & 7.2 \\
Little cigar & $7.80 \pm 0.05$ & $1.85 \pm 0.08$ & $228 \pm 41$ & 12.4 \\
\hline
\end{tabular}

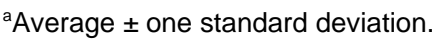

${ }^{\mathrm{b}}$ The total nicotine value for the 1R4F cigarette was taken from reference 12.

${ }^{\mathrm{c}}$ The treated non air-diluted cigarettes were treated for experimental purposes with ammonium carbonate to raise the $\mathrm{pH}$ as described in the Experimental section.

Table 5. Comparison of total \% vapor-phase nicotine to $\mathrm{pH}$ and total smoke nicotine for urea treated cigarettes ${ }^{\mathrm{a}}$

\begin{tabular}{c|c|c|c}
\hline Smoke $\mathrm{pH}^{\mathrm{b}}$ & $\begin{array}{c}\text { Total smoke } \\
\text { nicotine } \\
(\mathrm{mg} / \mathrm{cig})^{\mathrm{b}}\end{array}$ & $\begin{array}{c}\text { Total vapor- } \\
\text { phase nicotine } \\
(\mu \mathrm{g} / \text { cig })^{\mathrm{b}}\end{array}$ & $\begin{array}{c}\text { \% Total } \\
\text { vapor-phase } \\
\text { nicotine }\end{array}$ \\
\hline $6.47 \pm 0.15$ & $1.41 \pm 0.02$ & $494 \pm 146$ & 35.0 \\
$6.59 \pm 0.05$ & $1.37 \pm 0.05$ & $322 \pm 59$ & 23.5 \\
$6.59 \pm 0.07$ & $1.44 \pm 0.01$ & $389 \pm 212$ & 27.0 \\
$6.74 \pm 0.03$ & $1.35 \pm 0.07$ & $79.0 \pm 24.8$ & 5.9 \\
$7.15 \pm 0.19$ & $1.55 \pm 0.03$ & $134 \pm 47$ & 8.7 \\
\hline
\end{tabular}

aThe cigarettes were treated with urea for experimental purposes.

${ }^{\mathrm{b}}$ Average \pm one standard deviation.

phase. This was clearly demonstrated by comparing the results obtained for the urea treated cigarettes. These cigarettes differed in smoke $\mathrm{pH}$, yet the percent of initial vapor-phase nicotine yield was not directly related to this variable. Also noted is that the maximum amount of initial vapor-phase nicotine, or unprotonated nicotine, delivered to the mainstream smoke was only $2.1 \%$ of the total nicotine delivered. Though construction appeared to play a part in affecting vapor-phase nicotine yields, further studies are being conducted in order to determine whether construction variables, even when carried to impractical extremes, are sufficient to meaningfully affect nicotine phase distribution in mainstream cigarette smoke.

\section{ACKNOWLEDGEMENTS}

The authors gratefully acknowledge Rana Walker for her contributions to the solanesol determinations, Dr. Deborah Mereand for her assistance with statistical analysis of the data, Ken Barrett for preparation of the cigarette samples, and the Lorillard Glass Shop for their construction of the denuder tubes and configuration of the experimental apparatus. A thank you is also given to Marty Sudholt, Dr. Deborah Mereand, and Dr. Dan Heck for their useful discussions and comments, as well to the many other individuals who assisted in the editorial review of this work.

\section{REFERENCES}

1. Stedman, R.L.: The chemical composition of tobacco and tobacco smoke; Chem. Rev. 68(2) (1968) 153-207.

2. Seeman, J.I., J.A. Fournier, J.B. Paine III, B.E. Waymack: The form of nicotine in tobacco. Thermal transfer of nicotine and nicotine salts to nicotine in the gas phase; J. Agric. Food Chem. 47 (1999) 5133-5145.

3. Fournier, J.A., J.B. Paine III, J.I. Seeman, D.W. Armstrong, X. Chen: Thermal pathways for the transfer of amines, including nicotine, to the gas phase and aerosols; Heterocycles 55 (2001) 59-74.

4. Stevens, N A., M.F. Borgerding: GC-AED Studies of nicotine fate in a burning cigarette; Anal. Chem. 71 (1999) 2179-2185.

5. Eatough, D.J., K. Wooley, H. Tang, E.A. Lewis, L.D. Hansen, N.L. Eatough, M.W. Ogden: Sampling gaseous compounds in environmental tobacco smoke; Proceedings of the 1988 EPA/APCA International Symposium on Measurements of Toxic and Related Air Pollutants; Research Triangle Park, NC, 1988, pp. 739-749.

6. Lewis, D.A., I. Colbeck, D.C. Mariner: Diffusion denuder method for sampling vapor-phase nicotine in mainstream tobacco smoke; Anal. Chem. 66 (1994) 3525-3527.

7. Ogden, M.W., C. Maiolo, P.R. Nelson, D.L. Heavner, C.R. Green: Artefacts in determining the vapourparticulate phase distribution of environmental tobacco smoke nicotine; Environ. Technol. 14 (1993) 779-785.

8. Haeger, B., R. Niessner: On the distribution of nicotine between the gas and particle phase and its measurement; Aerosol Sci. Tech. 26 (1997) 163-174.

9. Eudy, L.W., F.A. Thome, D.L. Heavner, C.R. Green, B.J Ingebrethsen: Studies on the vapor-particulate phase distribution of environmental nicotine by selective trapping and detection methods; Presentation at the 79th Annual Meeting of the Air Pollution Control Association, Air Pollution Control Association, Minneapolis, MN, 1986, paper 86-38.7.

10. Williamson, J.T., D.R. Allman: The distribution of tobacco smoke constituents between the vapor and particulate phases; Beitr. Tabakforsch. 3 (1966) 590-596. 
11. Grob, K.: Zur Gewinnung und Behandlung frischer Gasphase aus Cigarettenrauch [Trapping and analysis of the gas phase of cigarette smoke]; Beitr. Tabakforsch. 3 (1965) 243-250.

12. Omori, F., N. Higashi, M. Chida, Y. Sone, S. Suhara: Internal standard-based analytical method for tobacco smoke vapor phase components; Beitr. Tabakforsch. Int. 18 (1999) 131-146.

13. Pankow, J.F., B.T. Mader, L.M. Isabelle, W. Lue, A. Pavlick, C. Liang: Conversion of nicotine in tobacco smoke to its volatile and available free-base form through the action of gaseous ammonia; Environ. Sci. Technol. 31 (1997) 2428-2433.

14. Eatough, D.J., C. Benner, R.L. Mooney, D. Bartholomew, D.S. Steiner, L.D. Hansen, J.D. Lamb, E.A. Lewis, N.L. Eatough: Gas and particle phase nicotine in environmental tobacco smoke; Presentation at the 79th Annual Meeting of the Air Pollution Control Association, Air Pollution Control Association, Minneapolis, MN, 1986, paper 86-68.5.

15. Mariner, D.C., B.E. Frost: Determination of nicotine evaporation from mainstream smoke using denuder tubes; Presentation at the 1998 Coresta Congress, Brighton, England, 1998, paper ST 18.

16. Eatough, D.J., C.L. Benner, L.D. Hansen, E.A. Lewis, N.L. Eatough, R.J. Farber; Determination of the phase distribution of semi-volatile organic compounds with diffusion denuders; Presentation at the 80th Annual Meeting of APCA, New York, NY, 1987, paper 8770.2 .

17. Lewis, D.A., I. Colbeck, D.C. Mariner: Dilution of mainstream tobacco smoke and its effects upon the evaporation and diffusion of nicotine; J. Aerosol Sci. 26 (1995) 841-846.

18. Gundel, L.A., D.A. Lane: Sorbent-coated diffusion denuders for direct measurement of gas/particle partitioning by semi-volatile organic compounds; Adv. Environ. 2 (1999) 287-332.

19. Perfetti, T.A. , B.M. Gordon, W.M. Coleman III, W.T. Morgan: Determination of the transfer efficiency of $d$ nicotine to mainstream smoke; Beitr. Tabakforsch. Int. 19 (2001) 237-244.
20. Diana, J.N., A. Vaught: The Tobacco and Health Research Institute: Research Cigarettes; The University of Kentucky Printing Service, Lexington, 1990.

21. Walker, R.T.; E.L. Butler, V. Norman, R.M. Striegel, M.A. Sudholt, C.S. Williard: A study of analytical methods for measuring smoke $\mathrm{pH}$; Presentation at the 52nd Tobacco Science Research Conference, Atlanta, GA, 1998, paper 9.

22. Rodgman, A.: "Smoke pH": A Review; Beitr. Tabakforsch. Int. 19 (2000) 117-139.

23. Dixon, M., K. Lambing, J.I. Seeman: Mini-Review on the transfer of nicotine from tobacco to the smoker. A brief review of ammonia and " $\mathrm{pH}$ " factors; Beitr. Tabakforsch. Int. 19 (2000) 103-113.

24. Baker, R.R.: Smoke chemistry; in: Tobacco. Production, chemistry and technology, edited by D.L. Davis and M.T. Nielsen, Blackwell Science, Oxford, 1999, pp. 398-439.

25. Wehlburg, A.F.: Cigars and cigarillos; in: Tobacco. Production, chemistry and technology, edited by D.L. Davis and M.T. Nielsen, Blackwell Science, Oxford, 1999, pp. 440-451.

26. Ogden, M.W., K.C. Maiolo: Comparison of GC and $\mathrm{LC}$ for determining solanesol in environmental tobacco smoke; LC-GC 10, 459-462.

\section{Address for correspondence}

Emily W. Cochran

A.W. Spears Research Center

Lorillard Tobacco Company

Greensboro, NC 27405

USA 